\title{
RESEARCH and EVALUATION \\ Political Actor or Policy Instrument? Governance Challenges in Australian Local Government
}

\section{Commonwealth Journal of Local Governance \\ Issue 12: May 2013 \\ http://epress.lib.uts.edu.au/ojs/index.php/cjlg}

\section{Dr Nicola Brackertz}

Swinburne University of Technology

Victoria

Australia

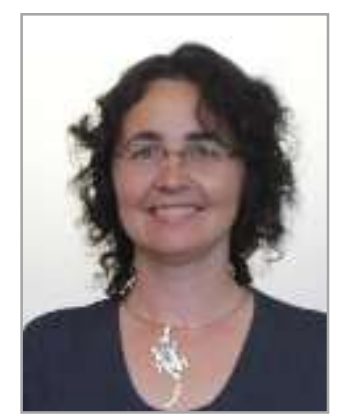

\begin{abstract}
This article examines the governance challenges facing Australian local government, which include lack of constitutional standing, intergovernmental dependencies, financial constraints and weak democratic standing. The historical context has shaped the nature and place of local government in the Australian federal polity and has contributed to the tensions created by an expansion of the roles and responsibilities of local government, especially in the provision of services, which is not matched by concomitant increases in financial capacity and local autonomy. These governance challenges are discussed with a view to establishing local government's capacity for autonomous self-governance in the face of intergovernmental and fiscal dependencies, and the implications of this for local government reform trajectories.
\end{abstract}

Key words: Local government, history, referendum, local government reform, local governance

\section{Introduction}

The remit and responsibilities of Australian local government have expanded significantly since the 1970s. There is now increasing emphasis on local government as a vehicle for responsive local governance, as a sphere for local democracy and community strengthening in the face of cynicism and democratic deficit, and in the provision of an increasing number of important services. However, the capacity of councils to fulfil these many new roles has not grown to a similar degree, and access to adequate finance and democratic safeguards are key concerns, creating a number of governance challenges. Many of the difficulties facing Australian local government have been captured in numerous national and State inquiries, which include, but are not limited to the 2001 Commonwealth Grants Commission's Review of the Operation of Local Government (Financial Assistance) Act 1995; the House of Representatives Standing Committee on Economics, Finance and Public Administration's Rates and Taxes: A Fair Share for Responsible Local Government, commonly known as the Hawker Report (2003); the Australian Local Government Association (ALGA) 
commissioned National Financial Sustainability Study of Local Government (PWC, 2006); and the Productivity Commission's Assessing Local Government Revenue Raising Capacity (PC, 2008). The Henry Tax review also has significant implications for local government (Henry et al 2009; Passant \& Mclaren, 2011). State-level inquiries have included the South Australian Local Government Association commissioned inquiry into the long-term financial sustainability of South Australian local government (FSRB, 2005a; 2005b); the Independent Inquiry in the Financial Sustainability of NSW Local Government (2006; Access Economics, 2006a); a Systemic Sustainability Study of Western Australian Local Government (Access Economics, 2006b; Craven et al, 2006; WLGA, 2008); a financial sustainability study commissioned by the Local Government of Tasmania (Access Economics, 2007); the Queensland Local Government Reform Commission's series of reports on the Size, Shape and Sustainability of Local Government (QTC, 2008; DLGPS\&R, 2007; LGAQ, 2005; LGAQ, 2006; LGRC, 2007); and the Municipal Association of Victoria's series of reports on Trends in Local Government Finance (MAV, 2005; 2010).

While the titles and foci of these inquires may lead one to believe that financial sustainability is the central defining issue facing local government in the first decade of the $21^{\text {st }}$ century, functional, democratic and constitutional issues also provide governance challenges, many of which are rooted in the historical development of Australian local government.

These governance challenges will now be discussed in turn, with a view to establishing local government's capacity for autonomous self-governance in the face of intergovernmental and fiscal dependencies, and the implications of this for local government reform trajectories.

\section{Four challenges for local governance}

Australian local government differs from many of its OECD counterparts. In the Australian federal system, local government fulfils only a limited number of functions and is often considered to be a 'lesser' part of government. This is due in part to historical factors, which have resulted in four governance challenges for local government:

1. Intergovernmental dependencies and the changing roles and responsibilities of local government

2. Financial constraints and dependencies

3. Ideas about local government as a site of grassroots democracy and responsive governance versus expectations that it be an efficient vehicle for the delivery of many important services and act as an 'executor' of State government policies and programs

4. Limitations on its sovereignty due to lack of constitutional recognition. 


\section{Challenge: intergovernmental dependencies and changing LG roles}

The role of Australian local government and intergovernmental relations were established early in the twentieth century. The importance of territory as an organising principle for governing was a central cause of the existence of local government, which was seen as an administrative adjunct to colonial regimes. It acted as a mechanism to transfer to the community the administrative and financial burden for the provision of basic local services. Consequently, it performed a narrow range of functions and there was a limited view of its role by the States and the Commonwealth. This also led to local government having a restricted view of its own role and capacity to act as part of the federal system (Chapman, 1997, p. 1).

Originally local government functioned as a ratepayer democracy (Zwart, 2003) concerned primarily to meet the needs and interests of landowners and ratepayers, rather than of all citizens. Services to property were at the core of its responsibilities, with provision of roads being the most urgent. The supply of water, electricity and transport was handled by specifically constituted State government bodies, as local authorities were not large enough, nor sufficiently resourced, to provide them (McNeil, 1997, p. 20). Due to the fact that local government maintained the focus on services to property, in all states it ended up with a range of minor and essentially similar functions (Gibbins 2001; McNeil, 1997, p.19). The doctrine of ultra vires reinforced the limited power of local governments, as they could only do those things for which they had been given express legislative authority or which were reasonably incidental to the local government Acts (Aulich 1999, p. 14).

Following the Second World War, local government functions broadened to include town planning and a range of welfare and leisure services (Bowman and Hampton, 1983, p. 169). However, until the 1970s, local councils were still largely considered to be responsible for only a restricted range of services with an emphasis on roads, rates and rubbish. Local government was 'not considered to be part of the governing system, but rather as a limited, functional managerial system' (Chapman and Wood, 1984, p. 14).

The Whitlam Labor government of 1972-75 heralded significant changes for local authorities, by considerably broadening the funding base and allowing councils diversity in the range of services they provided, expanding their sphere of action to encompass quality of life and wellbeing issues. Whitlam's policies for local government can be grouped into broad structural development relating to its constitutional position, explicit financial initiatives and regionalisation. Local government was granted attendance at the constitutional conventions of 1973-74.

Broadening of councils' financial base was another key policy. The Whitlam government expanded the role of the Commonwealth Grants Commission to examine applications from local governments and provide to them with Section 96 Financial Assistance Grants. General revenue assistance 
recognised new demands were being placed on local government in areas such as health and welfare. This strategy was intended to use grants to encourage the nationwide development of regional authorities (Lloyd and Reid, 1974, p. 286; c.f. Chapman, 1997, p. 3). In this way, the federal government used local government as a vehicle for the implementation of many policies the Commonwealth felt would have been blocked by States (Chapman, 1997, p. 1).

The Grants Commission Act 1973 (Cth) allowed local governments to make applications for financial assistance through approved regional organisations of councils. Regional Councils for Social Development were formed under the Australian Assistance Plan; Regional Organisations of Councils were intended to deal with the Grants Commission and were also used for the Area Improvement Program. The financial assistance - \$56 million in 1974-75 and \$79 million in 1975-76 - was warmly received by local authorities, but both State and local spheres feared that this proposal was a threat and was a first step in the creation of regional government, which would cause their demise. However, as Miles (1976, p. 180) observed, 'the regional organisation has, in relation to the Grants Commission, eventually served no purpose other than to act as a post office, or a convenient geographical location for hearing by the Commissions' (c.f. Chapman and Wood, 1984, p. 34), and little in the way of structural change eventuated. Another initiative was the funding of local government projects such as area improvement grants, tourism and recreation, sheltered employment, home nursing, delivered meals, aged persons' homes, childcare and preschools, regional employment development schemes and the Australian Assistance.

The Whitlam initiatives showed local government for the first time that it had some political power, although Chapman (1997) concludes that it was not ready to become a genuine partner in government due to weaknesses with the out dated organisation and legislation in all States.

After Whitlam's dismissal in 1975, the Fraser Liberal/National government established the Advisory Council for Intergovernmental Relations and, by guaranteeing local government a share of personal income tax through the Local Government (Personal Income Tax Sharing) Act 1976 (Cth), councils were allocated a fixed proportion of Commonwealth personal income tax revenue. Initially the percentage of these untied grants, known as PITs (personal income transfers), was set at $1.52 \%$, rising to $1.75 \%$ in $1979-80$ and to $2 \%$ in $1980-81$. In 1985-86 the Commonwealth ceased the tax sharing arrangement and introduced the Local Government Financial Assistance Act 1986 (Cth).

The Fraser government institutionalised specific purpose grants which continued to direct the services provided by local governments to broaden beyond infrastructure to increasingly provide a range of social services (McNeil, 1997, p. 26-7). This trend continues, and today, while the functions of local government still vary between the States and territories, they include: engineering; infrastructure and property services; recreation facilities; health services such as water and food inspection, immunisation services, toilet facilities, noise control, meat inspection and animal control; community 
and cultural services; building services; planning and development approval; water and sewerage services (in Queensland, Tasmania and rural New South Wales); and environmental management and planning. Local government is also an advocate and leader for the community, an agent for the delivery of services for other spheres of government, coordinator of services delivered at the local level, and an information broker (Commonwealth Grants Commission, 2001; ACLEG 2011).

The work of the Advisory Council for Intergovernmental Relations helped bring local government into the intergovernmental processes. Following from a recommendation by the 1973 constitutional convention, all States now recognise local government in their constitutions, though in various forms and with varying provisions. However, this provides only limited protection and certainty, as the provisions can be changed easily by State Parliaments. Consequently the State Constitutions provide only weak protection for the democratic status of local government (see also Hartwich 2009; Saunders, 2005). Furthermore, none spell out clearly the functions and fiscal structure of local government, which has been left to ordinary acts of State Parliaments.

Since the late 1980s there have been substantial reforms to the local government Acts in all States and the Northern Territory, with a move away from the doctrine of ultra vires. Councils are now enabled to undertake the full range of activities necessary to fulfil the functions and powers delegated to them. The new Acts aim to improve accountability mechanisms, reduce the detailed prescriptions, and change council boundaries either by choice or by force of law, and change planning and other delegated powers. However, all states and territories have retained overrule provisions in their local government legislation, and council can be merged, abolished or put under 'administration' by State governments, for example, in Victoria in the 1990s and in Queensland in 2008.

The legislative changes provided the necessary framework for wider microeconomic reforms in local government to improve its performance orientation, accountability and relations with other spheres of government (Wensing 1997, p. 27). Further reform focused on its governance role and sought to 'clarify the roles of State and local government, increase devolution and local capacity, mandate consultation and reporting as part of the strategic management process, and enhance provisions for referendums to ensure that councils are more accountable and responsive to the communities they serve' (Aulich 1999, p. 13).

The expansion of the role of local government has been partly due to devolution of functions by other spheres of government. Other factors are market deregulation, industrial relations reform, privatisation of public utilities and competition policy. Technological advancement and changing community expectations of government have also had a profound impact, with many councils expanding service provision in response to community demands. Local government reform programs, implemented by some State governments, caused far-reaching changes to the structure and operations of councils. A change of policy focus by local governments themselves has also contributed to their 
providing a wider range of services and taking a greater role in economic and social development and environmental management. The expansion in local government functions and range of services provided over recent decades, have led to a mismatch between expenditure demands and current levels of revenue, especially own-source revenues (ACELG 2011). This is felt particularly strongly by rural and regional councils and in the areas of infrastructure maintenance.

\section{Challenge: financial constraints and dependencies}

The perilous financial situation of Australian local government has been extensively discussed and has been the topic of numerous state and national inquiries (Access Economics, 2006a; 2006b; 2007; Commonwealth Grants Commission, 2001; Craven et al, 2006; Dollery, Crase and Byrnes, 2006; DLGPS\&R, 2007; FSRB, 2005a; 2005b; Hawker Report, 2003; Independent Inquiry in the Financial Sustainability of NSW Local Government 2006; LGAQ, 2005; 2006; LGRC, 2007PC, 2008; MAV, 2005; 2010; QTC, 2008; Tuckey, 2002; WALGA, 2008). Local government remains hamstrung by its reliance on funding from State and federal governments, as the reforms of the 1970s and 1990s did little to address the narrowness of its revenue resources. In his examination of federal-local relationships along the lines of constitutional recognition of local government, fiscal transfers between national and local governments, and intergovernmental relations between the two, Gibbins (2001) observes the Commonwealth's monopolisation of income and consumption tax results in a vertical fiscal imbalance (c.f. Chapman and Wood, 1984, p. 35-6). For example, since the abolition of PITs in 1985-86, local government's only direct source of tax income is property rates, which makes up only $3-4 \%$ of the total national tax collected, and only one third of national property taxes, the other two thirds being an integral part of State governments' revenue base (ALGA 2007).

This means that State and local authorities depend on the federal government for the bulk of their operating budgets. Gibbins (2001, p. 166) concludes that intergovernmental relations come hand in glove with fiscal entanglements, as they follow the fiscal rather than the constitutional channels.

Australian local government revenue in 2003-04 amounted to $\$ 20.3$ billion. The main sources were: taxation/rates of $37.8 \%$ ( $\$ 7.7$ billion); fees and user charges 30.5\% (\$6.2 billion); grants, e.g. specific purpose payments from federal government such as Roads to Recovery and financial assistance grants which are paid to State governments for distribution to local government via the State Grants Commission, $12 \%$ ( $\$ 2.4$ billion). Other income derives from investment interest, dividend interest: income from public enterprise, fines and the like, about 20\% ( $\$ 4$ billion).

In 2000-01 the Commonwealth Grants Commission undertook a review of the operation of the Local Government (Financial Assistance) Act 1995 which determines the amount of federal government grants to be paid. A number of its findings gave rise to concerns that the mix of Commonwealth and State funding changed over time to the detriment of local government, while the services provided by 
local government changed markedly, with an increased range of social welfare services at the expense of traditional property-based and infrastructure services. This was interpreted by the Federal Minister for Regional Services, Territories and Local Government, Wilson Tuckey, as providing evidential support that the increased local government functions and responsibilities, which are largely devolved from the States, were not matched by an increase in funding or an appropriate access to additional revenue (Tuckey, 2002, p. 6).

The Commonwealth Grants Commission (2001, p. 52-3) identified five main reasons contributing to the current financial crisis of local government. Devolution refers to the transfer of responsibilities for new functions from higher spheres of government. Raising the bar describes the requirement for increased complexity or standard at which local government services must be provided and an attendant increase in the cost of service provision. Cost shifting occurs when a municipal council agrees to provide an essential service on behalf of another sphere of government but subsequently funding is reduced or stopped and local government has to continue to provide the service. Cost shifting can also occur when another tier of government ceases to provide an essential service and local government is left to step into the breach. Increased community expectations and demands have broadened the range of services provided by local government and have led to improvements in existing services. Finally, individual councils' policy choice has led them to expand or enhance their range of services.

The Commission's findings contributed to the establishment of a House of Representatives Standing Committee on Economics, Finance and Public Administration inquiry into local government and cost shifting. Its report, Rates and Taxes: A Fair Share for Responsible Local Government (the Hawker Report), 'addressed not only the matter of cost shifting but also revealed the underlying issues relating to the governance arrangements between the three spheres of government', estimating the impact of cost shifting at $\$ 550$ million to $\$ 1.1$ billion a year:

There is no doubt that local government has, over a number of years, been on the wrong end of cost shifting largely by state governments. Cost shifting can be seen as a symptom of the current weaknesses in our system and it is the responsibility of all spheres of government to address the matter (House of Representatives Standing Committee on Economics, Finance and Public Administration 2003, vii).

On 23 June 2005, the Commonwealth government formally responded to the report, highlighting four priority areas which resulted from its 18 recommendations (Commonwealth of Australia and Department of Transport and Regional Services, 2005). It acknowledged that cost shifting and inadequacy of available financial resources were a significant problem, and accepted the recommendation to develop an intergovernmental agreement on these matters.

The Commonwealth also accepted the recommendations for a Productivity Commission study on barriers to local government revenue, which resulted in the Assessing Local Government Revenue 
Raising Capacity (2008) research report. This found that most local government revenue consisted of own-source revenues (rates, fees, and charges) and grants from other spheres of government and noted that all councils could do more to increase their own source revenues, with most urban councils being in a position to self-fund current levels of expenditure. However, the impact of this inquiry was limited, as the terms of reference excluded an assessment of the adequacy of Commonwealth financial assistance, focusing on local government own-source revenue and State government restrictions on these revenue sources. The Commonwealth also agreed to a review of interstate distribution of the identified roads component of financial assistance grants. Despite the formal acknowledgement of local government's financial situation, no comprehensive program has been put in place to address these issues. Vertical fiscal imbalances continue to limit local governments' financial autonomy and they are not fully resourced to fulfil the many roles required of them.

\section{Challenge: local democracy and legitimacy}

The contemporary debate on the status of local government began in the 1970s, coinciding with the election of the Whitlam government and renewed debates around local government as a site of responsive governance, democratisation and empowerment. In the 1980s a wave of public sector reform swept through all levels of the federal system, characterised by managerialism, marketisation and the new public management. The cumulative effect was a strong emphasis on neoliberal economic and neoconservative political principles and a shift from government to governance. Discussion of local government's role in democratic practice and as a vehicle for democratic legitimation gained renewed currency, especially in the context of neoliberal ideas about efficiency in service provision under network governance.

Direct citizen participation in local democracy is often cited as a remedy for the weak democratic legitimacy and accountability deficits associated with network governance, outsourcing and marketisation (Mulgan, 2006; Considine, 2002; Klausen and Sweeting, 2005; Rhodes 1997). Local engagement in the democratic sense is also seen as a measure to counteract the democratic deficit, providing a sphere for citizens to take direct action on issues that are important to them and contributing to the re-establishment of a sustainable community culture (Cox, 2000; Cuthill, 2003). Local government is seen to be ideally placed as the locus of direct citizen involvement because of its local knowledge and existing community ties and because it is closest to the people. As a consequence, it finds itself in the curious position of being singled out as the locus where the democratic deficiencies can be most effectively countered. Perversely, the existence and democratic nature of local government is not effectively guaranteed because it is not entrenched in the federal Constitution and because State constitutions provide comparatively weaker provisions for its ongoing democratic existence. 
Furthermore, while local government has a degree of legitimacy by virtue of being democratically elected, continued financial dependence on State governments means that, in the fiscal sense, it is not as accountable to its electorate as it is to the State governments (Hartwich, 2009, p. 7).

In 2003, the Hawker Report recommended the recognition of local government by both houses of federal Parliament, which was acted upon in 2006. A further amendment proposed by the Labor Party to include support for 'a referendum to extend constitutional recognition to local government in recognition of the essential role it plays in the governance of Australia' was rejected, indicating that while the Commonwealth Parliament recognised that local government has a legitimate place in the governance of Australia, there remained a degree of hesitation about ceding it too much power.

Nevertheless, the motion contributed to the renewed momentum to recognise local government in the federal Constitution. The status of local government in Australia's federal structure is an important issue, especially when considered in the context the tensions between expectations that it should function as a legitimate source of responsive and democratic local governance versus its roles in efficiently providing services.

\section{Challenge: lack of constitutional standing}

Prior to federation in 1901, legislation to provide legitimacy and a framework for the operations of local government had been enacted by each of the colonies. When the Australian Constitution was written, it did not include specific reference to local government. Chapman and Wood (1984, p. 30) argue that it was left out and was not discussed at the constitutional conventions because it was not considered important enough. Aulich and Pietsch (2002, p. 14) counter that this may be misleading as local government "does not appear to have been "excluded" in a deliberate sense - rather, there was little pressure for its inclusion'. In any case, the lack of inclusion in the constitutional process meant that local government did not take part in federation, 'a process in which the location of sovereignty and the distribution of powers and functions were at issue' (Chapman and Wood, 1984, p. 30). The consequences for local government autonomy and its status within the federal system were severe. It became a State statutory authority by default and was denied a place in the new national polity (Aulich and Pietsch, 2002, p. 14). State local government Acts were highly prescriptive of its roles, with councils seen as vehicles through which various statutory functions could be conducted and tasks delegated (Wensing, 1997, p. 26). It has contributed to the low status and low perceived legitimacy of local government, which is often referred to as a 'creature of the States' and is regarded as the 'third tier' or 'bottom tier'. This has also resulted in each State developing its own distinctive style of local government with considerable variation between and within States, which makes it difficult to talk of an Australian local government system. 
Following federation, the basic framework of Australian government remained remarkably stable until the 1970s when there was renewed discussion of local government's constitutional standing, its financial position and a broadening of the services provided by it. In Australia and internationally, ideas about local participation and democracy as a vehicle to empower local communities and facilitate responsive local governance were gaining new impetus. These ideas have not lost their currency, and indeed have gained credibility as a source of legitimacy for local decision making in the context of neoliberalism and the shift from government to governance.

Constitutional entrenchment has been proposed as a measure to enhance the legitimacy and the financial security of local governments, by eliminating the role of the States as the middlemen, thus increasing revenue and providing a broader funding base and greater access to federal tax revenues, enshrining their autonomy, and protecting them from dismissal by State governments.

Other perceived benefits are broader. Greater direct association between councils and the federal government could bring some beneficial uniformity to the regulation of local government, which differs markedly from State to State (Dollery, Crase and Byrnes, 2006; Kane, 2006, p. 25).

Constitutional recognition may also enhance local governments' abilities to coordinate their resources in strategically important areas such as water and environmental management, although this is already happening in many instances (ACELG 2011).

Achievement of these aims depends on the nature of the constitutional entrenchment sought, which could range from symbolic recognition to substantive constitutional protection, such as a guarantee of greater autonomy, clarity about tasks to be performed and access to sufficient revenue sources to undertake them.

The history of the quest for constitutional recognition shows that there are significant obstacles to be overcome, many of which are rooted in tensions about the locus of power between local government, the States and the Commonwealth, fiscal dependencies, and the stringent requirements for a referendum which require a national majority of voters and a majority of electors in at least four out of six States.

Section 128 of the Commonwealth of Australia Constitution Act 1900 (Cth), sets out the requirements for changes to the Constitution. Any proposed laws must be passed by an absolute majority (the total number of representatives in the chamber) of both Houses of Parliament, before being submitted to a referendum. If the two Houses disagree, the agreement of just one House is sufficient to initiate a referendum under the condition that a proposal has passed with an absolute majority and the other House 'rejects or fails to pass it, or passes it with any amendment to which the first-mentioned House will not agree'. 
Before proposals to amend the Constitution commence their passage through Parliament, they are generally preceded by debates in a range of formal (e.g. popular conventions, intergovernmental conventions such as the Australian Constitutional Convention, commissions, parliamentary committees, government, and interest groups) and informal fora (e.g. media, debates along party lines) (Williams and Hume, 2010).

In 1973 the Whitlam government introduced the Constitutional Alteration (Local Government Bodies) Bill to allow the federal government to provide funding directly to local governments. This was defeated in the Senate due to resistance from opposition parties who saw it as an affront to the States. Subsequently, a proposal to alter the Constitution to enable the Commonwealth to borrow money for, and grant financial assistance to, local government bodies rather than using States as conduits, was included in the referendum held on 18 May 1974 (Saunders, 2005).

The campaign for a 'no' vote was underpinned by suspicions about the reasons why local government was seeking constitutional recognition, and by the Whitlam government's agenda for regionalism. In essence, opponents considered local governments' constitutional aspirations as diminishing the power of the States and furthering centralist tendencies, and as a possible step towards establishing regional authorities (Kane, 2006, p. 26).

Had the referendum been successful, the new constitutional provision would have provided a symbolic recognition of local government and would have opened up new funding avenues. However, it would not have provided substantial constitutional protection for local government as a democratically elected, integral part of the federal polity.

The quest to increase the autonomy and standing of local government received new impetus at the constitutional referendum on 3 September 1988. This proposed the addition of a section 119A to the Constitution:

Each State shall provide for the establishment and continuance of a system of government, with local government bodies elected in accordance with the laws of the State and empowered to administer, and to make by-laws for, their respective areas in accordance with the laws of the State.

The 'no' case argued that the term 'system of local government' was vague and open to interpretation and that the proposed provision would not provide protection from arbitrary dismissal and did not provide further clarity on the structure, role and basic rights and responsibilities of local government. The argument that the proposal was a step towards strengthening the power of the Commonwealth was revived with rather dramatic statement:

This proposal changes nothing for Australians - except for the worse. And again, it panders to the federal Government's increasing desire for more power, centred in Canberra. STOP CANBERRA'S POWER GRAB. PROTECT YOUR SYSTEM OF LOCAL GOVERNMENT. VOTE NO (Commonwealth of Australia, 1988, p 20). 
The referendum was soundly defeated, with only $33.61 \%$ of votes in favour. As in 1974, the negative outcome was the result of a sustained and successful campaign by opponents and a lack of bipartisan support. Consequently the result was due largely to political factors rather than the nature of the amendments sought.

This history of unsuccessful referendums is relevant today. It indicates that bipartisan support and backing from the States is essential to achieving constitutional recognition of local government, a fact recognised in the Expert Panel on Constitutional Recognition of Local Government's Final Report (2011) which assessed the parameters of the current proposal for a third referendum on the issue. Importantly, the report identified that the underlying issues affecting the success of previous campaigns have not been resolved, as reflected in the States' and Territories' varying levels of support for and opposition to the four proposed types of amendments: symbolic recognition in a preamble to the Constitution, financial recognition, democratic recognition and federal cooperation.

A key contention is about the impact of any proposed changes on the locus of power in the federal system, particularly the historic tension between local government as an instrument of national policy versus its function as a vehicle through which to implement activities and policies as seen fit by the State and territory governments - a tension which is closely tied to the financial entanglements described earlier. A contributing factor and current pressing issue is the recent High Court finding in Pape v Commissioner of Taxation (2009) 238 CLR 1 which has cast doubt on the constitutional validity of the Commonwealth making direct grants to local government. These factors and concerns about the financial sustainability of local governments, as outlined in the Hawker Report, contributed to the Expert Panel report indicating that a referendum around financial recognition was a preferred and potentially viable option for a referendum in 2013 , as it has the highest level of support politically (at State and federal levels), is viewed favourably by 75\% of the public (Expert Panel, 2011, p. 40) and is most likely to make a material difference to the financial situation of local government. At the same time the Panel advised caution, noting 'that financial recognition per se does not currently enjoy sufficient support either among stakeholders or the general community to give a referendum a high enough prospect of success in this Parliament' (Expert Panel, 2011, p. 2).

Democratic recognition - changing the Constitution to guarantee that local councils are elected bodies - is the second preference identified by the Expert Panel. However, this option does not attract the same amount of political support. Key stakeholders including the federal opposition and several State governments opposed this (Expert Panel, p. 8) on the basis that it would limit the States' and Territories' ability to supervise, oversee, manage and reform local councils, especially in the case of corrupt or dysfunctional councils. The argument is that, under existing State Acts, local governments are already elected. While democratic recognition would strengthen this provision, most States' 
submissions to the Expert Panel advanced the view that 'there is nothing to be gained by including similar provisions in the Commonwealth Constitution' (WA submission, Submission no 572, p. 2).

Interestingly, the option of democratic recognition attracted the highest level of public support. Polling indicated that the people are sympathetic to a referendum on democratic recognition, possibly because this appeals to 'a higher level concept than the institution of local government itself' (Expert Panel, 2011, p. 8). This may indicate that there is a popular desire for local government to become a recognised and safeguarded part of the democratic polity. However, despite wide public support for the democratic option (85\% supportive and 65\% strongly supportive (Expert Panel, 2011, p. 40), previous referendums have shown that initial support for a referendum does not necessarily translate into a positive result, thus caution is advised.

The two other options investigated by the Expert Panel - symbolic recognition and recognition through federal cooperation - were seen as unlikely to succeed. While symbolic recognition, that is of the inclusion of local government in the Constitution in a way that has no real legal effect (possibly in a preamble), was the second most popular option in submissions (Expert Panel, 2011, p. 10), it received little support from stakeholders or in public consultation, largely because it was seen to have little practical effect and be largely tokenistic. The final option, changing the Constitution to explicitly encourage cooperation between the governments of the federal system, was too new for most stakeholders and members of the Expert Panel to elicit much comment or debate and was seen to involve complex technical and legal matters regarding the federal balance of power.

In summary, the submissions to and report of the Expert Panel indicate that many issues that worked against successful referendums in the past remain unresolved. It is not that the matters under consideration lack merit or support in principle, rather it is well established that political factors, uncertainty about the relative importance of the issues and conflicting views about the appropriate nature of constitutional entrenchment are ongoing challenges for the referendum process.

\section{Conclusion}

Although wide-ranging reforms have strengthened local governments' roles and status since the 1970s, their capacity to fulfil these expectations has not grown to the same degree. In part this is due to constitutional issues, in part due to financial constraints and in part due to the historical evolution of local government in Australia, which has affected the way it sees itself and the way it is perceived by other spheres of government and the public. In particular, there appears to be a persistent reluctance on the part of local government to take up its own cause and initiate change. This is evidenced, for example, by the fact that although local government peak bodies have initiated a number of inquiries, local government has been hesitant to put together and action packages of 
reforms, leaving responses to the recommendations of inquires largely to state and federal governments.

Access to finance and safeguard of democratically elected councils from arbitrary dismissal remain key concerns that need to be addressed. Whether the constitutional route is the best way to deal with these issues is open to debate, as historically, structurally, legally and politically the chance of success of a referendum is slim. State and federal government opposition to democratic recognition in the Constitution demonstrates an ongoing scepticism about local government's capacity to democratically and effectively administer and govern local affairs and a perception that it is in need of ongoing 'supervision' by the States which must intervene if the situation becomes corrupt or dysfunctional (Expert Panel, 2011, p. 9). At a deeper level it demonstrates that the States, territories and federal government are wedded to the idea of local government as a functional and administrative extension of their own policy agendas. Thus, while there is much talk about local government as a site of authentic democratic governance and its attendant benefits (increased civic capacity, higher social capital, more effective and responsive provision of service), this is only supported as long as it suits the agendas set by State, territory and federal governments. This makes it akin to an experiment in democracy that can be terminated if it does not suit the political agendas of the higher levels of government, as in Victoria in the 1990s.

Alternatives to constitutional change include changes to State legislations to secure the autonomy of local government, coupled with initiatives and legislation to improve local governance and administrative reform. This would require concerted and coordinated action on behalf of local government and points to a further governance challenge, namely the need for local government to step up as a political actor in the federal system, advocating on its own behalf.

\section{References}

Access Economics (2006a) Local Government Finances in New South Wales: An Assessment, Research Report for the Independent Inquiry into the Financial Sustainability of NSW Local Government, Sydney.

Access Economic (2006b) Local Government Finances in Western Australia, Research Report for the Western Australian Local Government Association, Perth.

Access Economics (2007) A Review of the Financial Sustainability of Local Government in Tasmania, A Report for the Local Government Association of Tasmania, Hobart.

Australian Centre of Excellence for Local Government (ACELG) (2011) Unfinished Business? A Decade of Inquiries into Australian Local Government, Working Paper No.4 (University of Technology Sydney: Sydney).

Australian Local Government Association (ALGA) (2007) Financing Local Government. Productivity Commission Study into Local Government's Own-source Revenue. Australian Local Government Association Submission July 2007, Canberra.

Aulich, C.(1999) From Convergence to Divergence: Reforming Australian Local Government, Australian Journal of Public Administration, 58(2), pp. 12-23.

Aulich, C. \& Pietsch, R. (2002) Left on the Shelf: Local Government and the Australian Constitution, Australian Journal of Public Administration, 61(4), pp. 14-23. 
Bowman, M. \& Hampton, W. (1983) Local Democracies: A Study in Comparative Local Government (Melbourne: Longman Cheshire).

Brown, A. (2002) Subsidiarity or Subterfuge? Resolving the Future of Local Government in the Australian Federal System, Australian Journal of Public Administration, 31(4): 24-42.

Chapman, R. (1997) The Role of Local Government in Australia, in M. Haward, R. Ryan \& B. Chapman (Eds), Local Government Restructuring in Australasia, pp. 1-23 (Hobart: Centre for Public Management and Policy, University of Tasmania).

Chapman, R. \& Wood, M. (1984) Australian Local Government: The Federal Dimension (Sydney: Allen \& Unwin).

Commonwealth Grants Commission (2001) Review of the Operation of the Local Government (Financial Assistance) Act 1995 (Canberra: Commonwealth Grants Commission). http://www.cgc.gov.au/_data/assets/pdf_file/0003/2748/Final_Report.pdf (accessed 16 January 2012).

Commonwealth of Australia (1988) Yes or No? Referendums. Saturday 3 September 1988. The Cases For and Against.

Commonwealth of Australia \& Department of Transport and Regional Services (2005) Government Response to the Report of the House of Representatives Standing Committee on Economics, Finance and Public Administration. Rates and Taxes: A Fair Share for Responsible Local Government (Canberra: Australian Government Printer).

Considine, M. (2002) The End of the Line? Accountable Governance in the Age of Networks, Partnerships, and Joined-Up Services, Governance: An International Journal of Policy, Administration, and Institutions, 15(1), pp. 21-40.

Cox, E. (2000) Creating a More Civil Society: Community Level Indicators of Social Capital, Just Policy, 19/20, pp.100-7.

Craven, G., McKenzie, F. \& McCullagh, G. (2006) In Your Hands: Shaping the future of Local Government in Western Australia, Systemic Sustainability Study (Western Australian Local Government Association: Perth).

Cuthill, M. (2003) The Contribution of Human and Social Capital to Building Community Well-being: A Research Agenda Relating to Citizen Participation in Local Government in Australia, Urban Policy and Research, 21(4), pp. 373-91.

Department of Local Government, Planning, Sport and Recreation, Queensland (DLGPS\&R) (2007) Local Government Reform (DLGPS\&R: Brisbane).

Dollery, B., Crase, L. \& Byrnes, J. (2006) Local Government Failure: Why Does Australian Local Government Experience Permanent Financial Austerity?, Australian Journal of Political Science, 41(3), pp. 339-53.

Dollery, B., Marshall. N. \& Worthington, A. (2003) Reshaping Australian Local Government: Finance, Governance and Reform (Sydney: UNSW Press).

Expert Panel (2011) Final Report (Canberra: Expert Panel on Constitutional Recognition of Local Government, Commonwealth of Australia represented by the Expert Panel Secretariat within the Department of Regional Australia, Regional Development and Local Government). http://www.localgovrecognition.gov.au/content/final-report (accessed 7 January 2012).

Financial Sustainability Review Board (FSRB) (2005a) Rising to the Challenge: Volume 1-Overview (Local Government Association of South Australia: Adelaide).

Financial Sustainability Review Board (FSRB) (2005b) Rising to the Challenge: Volume 2 - Supporting Analysis (Local Government Association of South Australia: Adelaide).

Gibbins, R. (2001) Local Governance and Federal Political Systems, International Social Science Journal, 53(167), pp. 163-70.

Hartwich, O.M. (2009) Beyond Symbolism: Finding a Place for Local Government in Australia's Constitution, Issue Analysis, 104 (Sydney: Centre for Independent Studies). http://www.cis.org.au/images/stories/issue-analysis/ia104.pdf (accessed 16 January 2012). 
Hawker report (2003) House of Representatives Standing Committee on Economics, Finance and Public Administration Rates and Taxes: A Fair Share for Responsible Local Government (Canberra: Commonwealth of Australia).

Henry, K (Henry Review) (2009) Australia's Future Tax System: Report to the Treasurer (Commonwealth of Australia: Canberra).

House of Representatives Standing Committee on Economics, Finance and Public Administration (Hawker Report) (2003) Rates and Taxes: A Fair Share for Responsible Local Government (Canberra: Commonwealth of Australia).

Independent Inquiry into the Financial Sustainability of NSW Local Government (2006) Are Councils Sustainable? Final Report: Findings and Recommendations (NSW Local Government and Shires Associations: Sydney).

Kane, J. (2006) Constitutionalising Local Government, Public Administration Today, 8, pp. $24-6$.

Klausen, J.E. \& Sweeting, D. (2005) Legitimacy and community involvement in local governance, in M. Haus, H. Heinelt \& M. Stewart (Eds.), Urban Governance and Democracy: Leadership and Community Involvement, pp.214-233 (Routledge: London).

Lloyd, C. \& Reid, G. (1974) Out of the Wilderness: The Return of Labor (Melbourne: Cassell).

Local Government Association of Queensland (LGAQ) (2005) Size, Shape and Sustainability of Queensland Local Government: Discussion Paper (LGAQ: Brisbane).

Local Government Association of Queensland (LGAQ) (2006) Size, Shape and Sustainability: Guidelines Kit (Local Government Association of Queensland: Brisbane).

Local Government Reform Commission, Queensland (LGRC) (2007) Report of the Local Government Reform Commission (LGRC: Brisbane).

McNeil, J. (1997) Local Government in the Australian Federal System, in B. Dollery \& N. Marshall (Eds.), Australian Local Government: Reform and Renewal, pp.17-39 (Macmillan: Melbourne).

Miles, N. (1976) Local Government and Federal Initiatives, in R. Mathews (ed.), Making Federalism Work: Towards a More Efficient, Equitable and Responsive Federal System, (Canberra: Centre for Research on Federal Financial Relations, Australian National University).

Mulgan, R. (2006) Government Accountability for Outsourced Services, Australian Journal of Public Administration, 65(2), pp. 48-58.

Municipal Association of Victoria (MAV) (2005) Trends in Local Government Finance (MAV: Melbourne).

Municipal Association of Victoria (MAV) (2010) Trends in Local Government Finance: 2007-08 Summary (MAV: Melbourne).

Passant, J. and McLaren, J. (2011) The 'Henry' Review of Australia's Future Tax System: Implications for Local Government, Working Paper No. 3, Australian Centre for Excellence for Local Government (University of Technology Sydney: Sydney).

Price Waterhouse Coopers (PWC) (2006) National Financial Sustainability Study of Local Government (Price Waterhouse Coopers: Sydney).

Productivity Commission (PC) (2008) Assessing Local Government Revenue Raising Capacity, Research Report (Canberra: Australian Government Printer). http://www.pc.gov.au/projects/study/localgovernment/docs/finalreport (accessed 6 February 2013).

Queensland Treasury Corporation (QTC) (2008) Financial Sustainability in Queensland Local Government (QTC: Brisbane).

Rhodes, R. (1997) Understanding Governance: Policy Networks, Governance, Reflexivity and Accountability (Open University Press: Buckingham).

Saunders, C. (2005) Constitutional Recognition of Local Government in Australia, in N. Steytler (Ed.), The Place and the Role of Local Government in Federal Systems, Occasional Paper, pp. 47-64 (Johannesburg: Konrad-Adenauer-Stiftung).

Tuckey, W. (2002) Inquiry into Local Government Responsibilities and Funding, Australian Journal of Public Administration, 61(4), pp. 5-9. 
Wensing, E. (1997) Systemic Reform or Administrative Update? Recent Legislative Changes in Local Government Around Australia, in M. Haward, R. Ryan \& B. Chapman (Eds), Local Government Restructuring in Australasia, pp.24-44 (Hobart: Centre for Public Management and Policy, University of Tasmania).

Western Australian Local Government Association (WALGA) (2008) The Journey: Sustainability into the Future, Systemic Sustainability Study (WALGA: Perth).

Williams, G. \& Hume, D. (2010) People Power: The History and Future of the Referendum in Australia (Sydney: University of NSW Press).

Zwart, I. (2003) A Greener Alternative? Deliberative Democracy Meets Local Government in Australia, $\mathrm{PhD}$ thesis (Hobart: Faculty of Arts, University of Tasmania). 